\title{
MERCURY CONTENTS IN AQUATIC MACROPHYTES FROM TWO RESERVOIRS IN THE PARAÍBA DO SUL: GUANDÚ RIVER SYSTEM, SE BRAZIL
}

\author{
MOLISANI, M. M. ${ }^{1}$, ROCHA, R. ${ }^{2}$, MACHADO, W. ${ }^{2}$, \\ BARRETO, R. C. ${ }^{2}$ and LACERDA, L. D. ${ }^{1,3}$ \\ ${ }^{1}$ Instituto de Ciências do Mar, Universidade Federal do Ceará, \\ Av. Abolição, 3207, CEP 60185-081, Fortaleza, Brazil \\ ${ }^{2}$ Light SESA/UNESP, Gerência de Meio Ambiente e Segurança da área de Geração da Light SESA, \\ Piraí, RJ, Brazil, CEP 27175-000 \\ ${ }^{3}$ Dept. Geoquímica, Universidade Federal Fluminense, Niteroi, RJ, Brazil, CEP 24020-007 \\ Correspondence to: Luiz Drude de Lacerda, Instituto de Ciências do Mar, Universidade Federal do Ceará, \\ Av. Abolição, 3207, CEP 60185-081, Fortaleza, Brazil, e-mail: 1drude@ fortalnet.com.br \\ Received March 13, 2004 - Accepted April 28, 2004 - Distributed February 28, 2006
}

(With 2 figures)

\begin{abstract}
This paper reports on a study to determine the $\mathrm{Hg}$ content in the five most abundant aquatic macrophyte species (Elodea densa, Sagittaria montevidensis, Salvinia auriculata, Pistia stratiotes and Eichhornia crassipes) in two artificial reservoirs flooded by water diverted from the Paraíba do Sul river, SE Brazil. The potential of these species for $\mathrm{Hg}$ accumulation and their role in $\mathrm{Hg}$ transport along the river system due to macrophyte management were evaluated. Mercury concentrations were higher in free-floating than in rooted species. Roots were also richer in $\mathrm{Hg}$ than were leaves. Dry weight $\mathrm{Hg}$ concentrations in leaves and roots from all species varied from 46-246 ng.g ${ }^{-1}$ to 37-314 ng.g-1 ${ }^{-1}$, respectively. These values are higher than those reported for uncontaminated lakes in Brazil and in other tropical areas and similar to those reported for moderately contaminated sites. Mercury concentrations can be attributed to fluvial transport from the heavily industrialized Paraíba do Sul river basin. Intensive sampling of Pistia stratiotes from two sites in the Vigário reservoir was performed to evaluate the capacity of $\mathrm{Hg}$ incorporation in short periods of time. The results showed a significant negative correlation between $\mathrm{Hg}$ content and size class of individual plants, demonstrating the importance of juveniles, fast growing plants in absorbing $\mathrm{Hg}$. The foremost impact related to $\mathrm{Hg}$ contents in the studied area concerns the periodic removal of macrophytes for reservoir management, followed by disposal in nearby areas. This results in the mobilization of 0.52 to $1.3 \mathrm{Kg}$ of $\mathrm{Hg}$ per year, a significant fraction of the $\mathrm{Hg}$ burden present in reservoir waters. Disposal of such material may result in $\mathrm{Hg}$ leaching to river systems, affecting the $\mathrm{Hg}$ transfer throughout the basin.
\end{abstract}

Keywords: mercury, aquatic macrophytes, artificial reservoirs.

\section{RESUMO}

\section{Concentração de mercúrio em macrófitas aquáticas em duas represas no sistema Paraíba do Sul-Rio Guandu, SE do Brasil}

O presente estudo apresenta as concentrações de $\mathrm{Hg}$ em cinco espécies abundantes de macrófitas aquáticas (Elodea densa, Sagittaria montevidensis, Salvinia auriculata, Pistia stratiotes e Eichhornia crassipes) coletadas em duas represas que recebem águas da transposição do rio Paraíba do Sul, SE do Brasil. A acumulação de Hg nessas espécies e seu papel no transporte de $\mathrm{Hg}$ ao longo do sistema fluvial devido ao manejo das macrófitas são discutidos. As concentrações de $\mathrm{Hg}$ foram maiores nas macrófitas flutuantes que nas enraizadas. Em geral, as raízes apresentaram maiores concentrações de $\mathrm{Hg}$ que as folhas para todas as espécies. As concentrações de $\mathrm{Hg}$ variaram de acordo com as espécies entre 46-246 ng. $\mathrm{g}^{-1}$ e 37-314 ng.g ${ }^{-1}$, 
respectivamente. Estas concentrações são maiores que aquelas relatadas para macrófitas coletadas em lagos não contaminados no Brasil e em outras regiões tropicais, e similares àquelas relatadas para áreas moderadamente contaminadas. As concentrações de Hg podem ser atribuídas ao transporte fluvial a partir da região industrializada do vale do rio Paraíba do Sul. Uma amostragem intensiva de Pistia stratiotes na represa do Vigário foi realizada para avaliar a capacidade de incorporação de Hg por esta macrófita. Os resultados mostraram uma correlação negativa, significativa, entre as concentrações de $\mathrm{Hg}$ e o tamanho dos indivíduos, demonstrando a importância de juvenis desta espécie na absorção de $\mathrm{Hg}$. A retirada periódica de macrófitas da represa, seguida por sua disposição em áreas adjacentes, pode afetar a dinâmica do Hg. Os resultados mostram uma mobilização de 0,52 a $1,3 \mathrm{~kg} \mathrm{Hg}$ por ano, uma fração significativa da carga total de $\mathrm{Hg}$ presente nas águas da represa. A disposição inadequada deste material poderá resultar em um aumento da mobilização de $\mathrm{Hg}$ na bacia.

Palavras-chave: mercúrio, macrófitas aquáticas, represas.

\section{INTRODUCTION}

Aquatic macrophytes accumulate $\mathrm{Hg}$ with high concentration factors relative to the $\mathrm{Hg}$ concentrations present in water, thus affecting the distribution of this metal among the different compartments of aquatic systems (Lacerda et al., 1991; Dushenko et al., 1995; Villar et al., 1999). Also, macrophyte rhizospheres are important sites of $\mathrm{Hg}$ methylation in tropical freshwater ecosystems (Guimarães et al., 1998; 2002), acting as a potential $\mathrm{Hg}$ source for herbivorous organisms and enhancing $\mathrm{Hg}$ transfer along food chains (Suarez et al., 2001).

The extensive growth and large biomass of aquatic macrophytes observed in tropical reservoirs may influence the $\mathrm{Hg}$ balance and distribution among reservoir compartments and alter the system's ability to retain pollutants. Therefore, reservoir management strategies such as the periodic removal of macrophytes and their disposal in nearby areas must take into consideration their effects on $\mathrm{Hg}$ mobilization.

The Paraíba do Sul river (PSR) is a natural link between Rio de Janeiro and São Paulo states, SE Brazil, receiving effluents from the largest industrialized region of the country. In the late 1950s, water from the PSR was diverted to form artificial reservoirs to supply water to the metropolitan area of Rio de Janeiro city, resulting in an artificial waterway - the PSR-Guandú river system (Fig. 1). After treatment, part of this water is discharged back into an artificial canal that flows into Sepetiba Bay, about $100 \mathrm{Km}$ from the PSR, an important fishery and tourism pole of southern Rio de Janeiro state. This has resulted in an increase in the freshwater flux to the bay from the original $20 \mathrm{~m}^{3} \cdot \mathrm{s}^{-1}$ to $160 \mathrm{~m}^{3} \cdot \mathrm{s}^{-1}$ (Molisani et al., 2002). Marins et al. (1999) suggested that the PSR may also be an important source of pollutants flowing into Sepetiba Bay. A preliminary mass balance calculation showed that the $\mathrm{Hg}$ load brought into Sepetiba Bay by the PSR-Guandú river system represents about $30 \%$ of the total $\mathrm{Hg}$ dis- charged into Sepetiba Bay (Marins et al., 1999). Further studies on the $\mathrm{Hg}$ distribution along the entire length of the waterway systems confirmed this calculation (Molisani et al., 2002). Two reservoirs, Santana and Vigário, control the system's water discharge and retain most of the suspended matter, and possibly associated pollutants, from the contaminated PSR. Both present extensive macrophyte growth due to partially eutrophicated waters. Therefore, macrophytes may play a significant role in the Hg dynamics through the PSR-Guandú system waterway.

In order to investigate the importance of aquatic macrophytes in the $\mathrm{Hg}$ dynamics of the PSR-Guandú system, we studied the distribution of $\mathrm{Hg}$ in the most abundant macrophyte species in the two reservoirs that control the water flux through the system.

\section{MATERIAL AND METHODS}

\section{Study site}

The two most important reservoirs in the Paraíba do Sul-Guandú river system were sampled. Santana reservoir has a watershed of $433 \mathrm{Km}^{2}$ and covers an area of $5.95 \mathrm{Km}^{2}$ with a mean depth of 3.3 meters. Vigário reservoir has a watershed of $30 \mathrm{Km}^{2}$ and an area of $3.8 \mathrm{Km}^{2}$ with a mean depth of $13.5 \mathrm{~m}$. The widespread distribution of aquatic macrophytes is evident in the two reservoirs. Their spatial distribution is determined by environmental conditions, particularly morphometric variables such as reservoir width, depth and width/wetted perimeter ratio, current velocities and water chemistry (Gantes \& Caro, 2001; Heegaard et al., 2001). In the study area, Elodea densa Planchon and Sagittaria montevidensis Bogin are present only in Santana reservoir, which is less deep, with many sediment banks and is a suitable habitat for rooted macrophytes. The greater depth of Vigário reservoir and its steep banks provide habitat only for the free-floating 


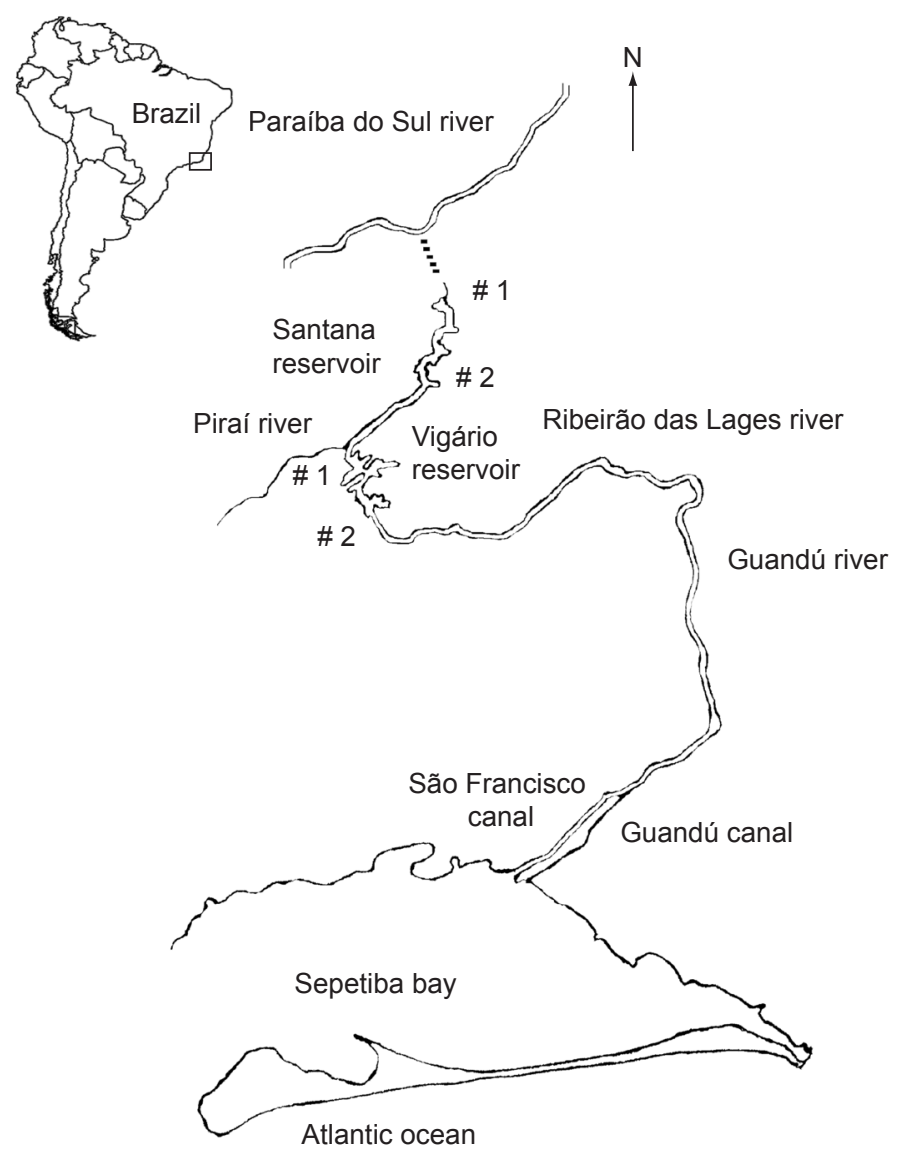

Fig. 1 - Scheme of the water diversion system of the Paraíba do Sul river to Sepetiba bay and sampling sites (scale 1: 400,000) (Molisani et al., 2002).

species Salvinia auriculata Aublet, Pistia stratiotes Linnaeus and Eichhornia crassipes Solms-Laubach. Rooted macrophytes occur as belts along shallow shores, whereas floating macrophytes occur both as small mats floating on the reservoir surface and as continuous cross-sectional covers. In both reservoirs, macrophytes are artificially managed and periodically removed. Removed plants, however, are frequently dumped locally.

\section{Sampling and chemical analyses}

Two samplings were carried out in Santana reservoir and three in Vigário reservoir between March 2001 and February 2002. Samples of E. densa $(\mathrm{n}=8)$ were collected in Santana reservoir at a depth of about $1 \mathrm{~m}$ at two sites (sites 1 and 2), while for $S$. montevidensis about 5 plants were sampled at one site (site 2 ) of the reservoir. In Vigário reservoir, 5 composite samples of $S$. auriculata, $P$. stratiotes and E. crassipes were collected from two sampling sites, in the middle (site 1) and lower (site 2) reservoir (Fig. 1). Each composite sample consisted of 10 to 20 individual plants. The plant samples were washed in lake water to remove particles of sediment, put into plastic bags and taken to the laboratory. In February 2002, an intensive sampling of $P$. stratiotes was performed at the Vigário reservoir. A large number of plants ranging in size from juveniles to full adult individuals were sampled in order to estimate the importance of the artificial management of this species in removing $\mathrm{Hg}$ from the reservoir.

In the laboratory, the samples were washed and roots and leaves were separated and dried at $50{ }^{\circ} \mathrm{C}$ for $24 \mathrm{~h}$. The $\mathrm{Hg}$ content was determined in duplicate after digestion of $1 \mathrm{~g}$ sub-samples in $20 \mathrm{~mL}$ of concentrated $\mathrm{HNO}_{3}$ for $1 \mathrm{~h}$ at $70{ }^{\circ} \mathrm{C}$ in a "cold-finger" system. After cooling, $20 \mathrm{~mL}$ of $\mathrm{HCl} 50 \%$ was added and the mixture heated at $70{ }^{\circ} \mathrm{C}$ for one hour. The $\mathrm{Hg}$ concentration was determined by cold vapor atomic absorption spectrophotometry. The accuracy of $\mathrm{Hg}$ determination in plant tissues was assessed using standard reference material SRM 1515 (Apple Leaves), reaching acceptable $(<15 \%$ difference) results $\left(53+3 \mathrm{ng} \cdot \mathrm{g}^{-1}\right.$ and $\left.44+4 \mathrm{ng} \cdot \mathrm{g}^{-1} ; \mathrm{n}=3\right)$ for the measured and certified values, respectively.

Water and sediment samples were collected from 
two sites in each reservoir in March 2001. All the sampling and analytical equipment was pre-cleaned according to acceptable protocols (Guentzel et al., 1996). The water samples were stored in $0.5 \mathrm{~L}$ pre-cleaned PET bottles (Copeland et al., 1996). The sampling bottles were rinsed three times with local water before being filled, double bagged in acid-washed plastic bags and transported in an icebox to the laboratory. Bottom sediments were taken manually with a Teflon shovel and stored in plastic bags.

Total dissolved $\mathrm{Hg}$ concentration in reservoir water was determined in unfiltered, non-acidified, sub-samples $(50 \mathrm{~mL})$ after oxidation with $0.2 \mathrm{~mL}$ of a bromine mono-chloride solution $\left(0.1 \mathrm{~mL} \mathrm{KBrO}_{3} 1 \% \mathrm{~m} / \mathrm{v}+0.1 \mathrm{~mL}\right.$ $\mathrm{HCl} 20 \% \mathrm{v} / \mathrm{v}$ ) at room temperature (Lacerda \& Gonçalves, 2001) through cold vapor atomic fluorescence in a Tekran Model 2500 AFS. The detection limit for the method is 0.2 ng. $\mathrm{L}^{-1}$.

The Hg concentrations in suspended particles (separated through filtering with Millipore $0.45 \mu \mathrm{m}$ cellulose acetate filters) and bottom sediments were determined after extraction with $20 \mathrm{~mL} 3: \mathrm{HCl}$ and $1: \mathrm{HNO}_{3} 50 \% \mathrm{v} / \mathrm{v}$ for $1 \mathrm{~h}$ in $60{ }^{\circ} \mathrm{C}$ using a "cold-finger system" (Lacerda \& Gonçalves, 2001). The Hg in sediments was determined by cold vapor atomic absorption spectrophotometry following reduction with $\mathrm{SnCl}_{2}$, in a Bacharatt Model Mercury Analyzer. The accuracy of the $\mathrm{Hg}$ determination in sediment samples was assessed by simultaneous analysis of reference material (NIST 2704 Buffalo River), reaching $58+3 \mathrm{ng} \cdot \mathrm{g}^{-1}(\mathrm{n}=5)$ compared with a certified value of $60 \mathrm{ng} \mathrm{g}^{-1}$.

\section{RESULTS AND DISCUSSION}

Table 1 shows the $\mathrm{Hg}$ concentrations in leaves and roots of studied species sampled in Santana and Vigário reservoirs. Within the same plant species and particularly in free-floating macrophytes, the $\mathrm{Hg}$ concentration was generally higher in root than in leaf tissues, with the excep- tion of E. crassipes from Vigário reservoir, which showed similar $\mathrm{Hg}$ concentrations in leaves and roots, and Sagitaria montevidense from Santana reservoir, which showed higher concentrations in leaves. The results agree, in general, with the reported pattern of $\mathrm{Hg}$ distribution in aquatic macrophytes (e.g. Aula et al., 1994; 1995; Gupta \& Chandra, 1998; Coquery \& Welbourn, 1994), but the small number of samples and the relatively large variability within species hinder a better statistical analysis of these data.

The free-floating species, particularly the fast growing species $P$. stratiotes and $S$. auriculata from Vigário reservoir, displayed the highest $\mathrm{Hg}$ contents of all the species sampled, while the rooted emergent S. montividenses from Santana reservoir presented the lowest $\mathrm{Hg}$ concentrations. Metal accumulation in aquatic macrophytes is known to vary among species; for example, emergent aquatic macrophytes usually accumulate lower amounts of metals than submerged or floating species (Albers \& Camardese, 1993). Metal uptake by these plants is dependent on exposure pathways. While water is the main metal source for floating macrophytes radio-tracer studies have demonstrated that the underlying sediments is the principal pathway for metal uptake by rooted macrophytes (Jackson, 1998). Moreover, the proportion of $\mathrm{Hg}$ readily available for uptake by rooted aquatic macrophytes depends on sediment geochemistry rather than on total $\mathrm{Hg}$ concentration in sediments. Also, rooted macrophytes develop oxidized rhizospheres capable of immobilizing metals at the external surfaces of roots, acting as a barrier to metal uptake (Coquery \& Welbourn, 1995; Campbell et al., 1985).

The $\mathrm{Hg}$ content in the free-floating macrophytes $E$. crassipes $P$. stratiotes and $S$. auriculata is related to the $\mathrm{Hg}$ concentrations in water, while the $\mathrm{Hg}$ content in the rooted emergent $S$. montevidense and the rooted submerged $E$. densa species is related to the concentrations and availability in bottom sediments. In addition to water and bottom sediments, suspended sediments may be

TABLE 1

Mean, standard deviation and range of $\mathrm{Hg}$ concentrations (ng. $\left.{ }^{-1}\right)$ in aquatic macrophyte species from Santana and Vigário reservoirs, Rio de Janeiro State, SE Brazil.

\begin{tabular}{|l|l|l|c|c|}
\hline \multicolumn{1}{|c|}{ Species } & \multicolumn{1}{c|}{ Type } & Reservoir & Leaf & Root \\
\hline Elodea densa $(\mathrm{n}=4)$ & Submerged & Santana & $82 \pm 57$ & $177 \pm 119$ \\
& & & $46-167$ & $106-314$ \\
\hline Sagitaria montevidense $(\mathrm{n}=4)$ & Emergent & Santana & $103 \pm 4$ & $62 \pm 35$ \\
& & & $100-106$ & $37-87$ \\
\hline Pistia stratiotes $(\mathrm{n}=5)$ & Free-floating & Vigário & $154 \pm 9$ & $215 \pm 60$ \\
& & & $146-167$ & $156-311$ \\
\hline Salvinia auriculata $(\mathrm{n}=5)$ & Free-floating & Vigário & $139 \pm 74$ & $191 \pm 75$ \\
& & & $85-246$ & $88-265$ \\
\hline Eichhronia crassipes $(\mathrm{n}=5)$ & Free-floating & Vigário & $125 \pm 40$ & $119 \pm 75$ \\
& & & $78-167$ & $101-136$ \\
\hline
\end{tabular}


considered a source of $\mathrm{Hg}$ for floating plants, since their roots act as traps for the suspended sediment flow and the particles adhering to roots are important sources of readily available $\mathrm{Hg}$ for plant uptake (Guimarães et al., 1998). Moreover, the general trend of lower $\mathrm{Hg}$ contents in the rooted $S$. montividenses and $E$. densa species than in the free-floating $P$. stratiotes, E. crassipes and S. auriculata may be influenced by the lower $\mathrm{Hg}$ concentrations in both water and sediments in Santana reservoir than in Vigário reservoir (Table 2).

A review published by Outridge \& Noller (1991) reported $\mathrm{Hg}$ concentration in freshwater plants from uncontaminated and contaminated environments to range from 20 to $19,000 \mathrm{ng} \cdot \mathrm{g}^{-1}$. These data demonstrate the considerable variations in $\mathrm{Hg}$ concentrations in aquatic macrophytes that settle in a wide diversity of aquatic environments. This wide range of concentrations is attributed to variables such as $\mathrm{Hg}$ partitioning in water and sediment, water physicochemistry, and plant physiology and genotypic features (Lacerda et al., 1991; Outridge \& Noller, 1991; Jackson, 1998; Maury-Brachet et al., 1990). Therefore, meaningful comparisons with literature data should at least be restricted to the tropics, notwithstanding the paucity of data from that region. Compared to other reported $\mathrm{Hg}$ concentrations in tropical aquatic mancrophytes, the concentrations found in leaves and roots of E. crassipes and $S$. auriculata in the reservoirs of the RPS-Guandú system are 2 to 3 -fold higher than those reported for the same species in large artificial reservoirs in the Brazilian Amazon (Aula et al., 1994) and from unpolluted Cuban waters (Gonzalez et al., 1994), which

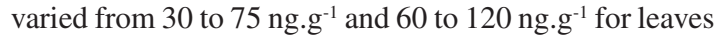
and roots, respectively. The concentrations found in the other species (P. stratiotes, S. montevidensis and E. densa) are also higher than the average concentrations found in mancrophytes from uncontaminated water bodies in Africa (Biney et al., 1994) and other parts of the tropics. In contrast, data from lowly to moderately contaminated sites in African aquatic environments showed $\mathrm{Hg}$ values in P. stratiotes and E. crassipes similar to those found in our study area (Biney et al., 1994). In several marginal lakes of the Madeira River in the western Amazon, which are affected by effluents from small-scale gold mining, $\mathrm{Hg}$ concentrations found in E. crassipes reached 1,000 ng. $\mathrm{g}^{-1}$
(Martinelli et al., 1988), i.e., well above the maximum concentrations found in our site. Though based on scanty data, it seems clear that the macrophytes from the PSRGuandú systems contain abnormal $\mathrm{Hg}$ concentrations, suggesting a major role in the transport of $\mathrm{Hg}$ through the system.

A sample of S. auriculata collected in a small lake located in the same drainage basin but outside the influence of the PSR-Guandú system showed a lower Hg concentration than those measured in the plants collected in Vigário reservoir $\left(63+38 \mathrm{ng} \cdot \mathrm{g}^{-1}\right.$ and $120+47 \mathrm{ng} \cdot \mathrm{g}^{-1}$ for leaves and roots, respectively). As a small artificial lake with no fluvial input, regional atmospheric deposition is most probably the only $\mathrm{Hg}$ source. Therefore, fluvial transport from the contaminated Paraíba do Sul river is responsible for the higher $\mathrm{Hg}$ concentrations found in macrophytes from the RPS-Guandú system's reservoirs.

The capacity of aquatic macrophytes to accumulate $\mathrm{Hg}$ can enable these plants to play at least three important roles in aquatic environments: as biomonitors of environmental Hg concentrations (Jackson et al., 1991); as conveyors of Hg to food chains Simon \& Boudou (2001); and as important sites for Hg methylation (Guimarães et al., 1998). Regarding the capacity for responding to environmental concentrations, the relationship between metal concentrations in the environment (water and substrate) and in the macrophytes showed that, at the very least, E. densa and P. stratiotes can be considered good monitors of $\mathrm{Hg}$ contents, the former in bottom sediments and the latter in the water column of the reservoirs studied here.

In the study area, however, another important role of aquatic macrophytes concerns their periodic removal from reservoirs for their management and their disposal in surrounding areas, which may be enriched by $\mathrm{Hg}$ due to decomposition of plant material; this may significantly affect $\mathrm{Hg}$ transport through the RPS-Guandú system. Intensive sampling of P. stratiotes at two sites in Vigário reservoir was done in order to estimate the capacity of $\mathrm{Hg}$ incorporation in short periods of time by juveniles of this species, since macrophyte removal may occur as frequently as at monthly intervals. Fig. 2 presents the concentration of $\mathrm{Hg}$ in plants distributed according to size classes, which included juveniles and mature individuals. The results revealed a significant negative correlation

TABLE 2

Mean Hg concentration in water and sediment samples from the Santana and Vigário Reservoirs $(n=4)$.

\begin{tabular}{|c|c|c|c|}
\hline Reservoir & Water $^{1}$ (ng.L $\mathbf{L}^{-1}$ ) & Suspended particles (ng.g $\left.{ }^{-1}\right)$ & Bottom sediments (ng.g ${ }^{-1}$ ) \\
\hline Santana & $\begin{array}{l}0.05-0.10 \\
0.08 \pm 0.03\end{array}$ & $\begin{array}{l}320-550 \\
390 \pm 100\end{array}$ & $\begin{array}{l}15-22 \\
19 \pm 3\end{array}$ \\
\hline Vigário & $\begin{array}{r}0.05-0.18 \\
0.1 \pm 0.07\end{array}$ & $\begin{array}{r}600-1,046 \\
1,130 \pm 430\end{array}$ & $\begin{array}{l}70-90 \\
80 \pm 14\end{array}$ \\
\hline
\end{tabular}




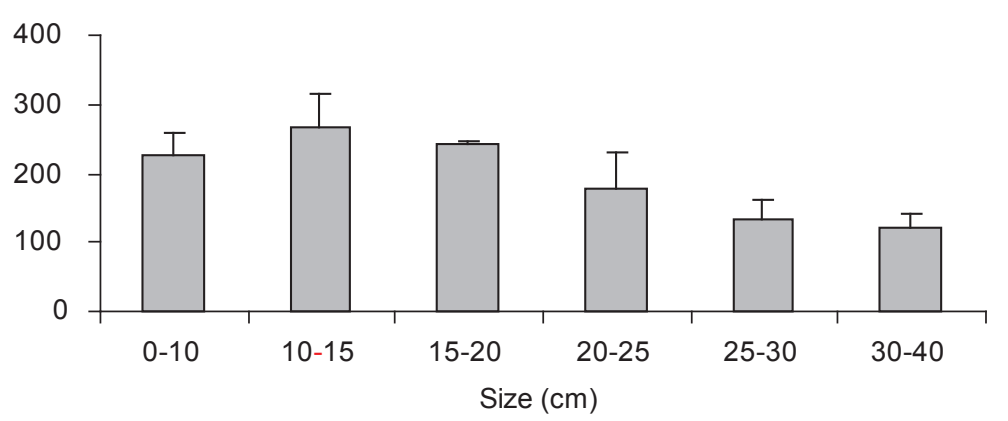

Fig. 2 - Mean $\mathrm{Hg}$ concentration (ng. $\mathrm{g}^{-1}$ ) in different size classes of Pistia stratiotes collected from two sampling sites in the Vigário reservoir ( $\mathrm{n}=6$ for each size class) (Molisani et al., 2002).

( $\mathrm{r}=-0.88 ; \mathrm{p}<0.05)$ between $\mathrm{Hg}$ concentrations and size. The higher $\mathrm{Hg}$ concentration in smaller individuals relative to adult plants demonstrates the importance of juveniles in absorbing $\mathrm{Hg}$ from the water, suggesting the biomonitoring value of juvenile individuals in monitoring studies of $\mathrm{Hg}$ contamination of these environments. On the other hand, the lower $\mathrm{Hg}$ content in adult plants suggests a dilution effect on $\mathrm{Hg}$ content as the plant's biomass increases. This finding confirms the potential importance of macrophyte removal in affecting the $\mathrm{Hg}$ dynamics in the system, since the plants may accumulate high $\mathrm{Hg}$ concentrations even within short periods.

To estimate the amount of $\mathrm{Hg}$ involved in the process, the amount of plants removed from the reservoir was monitored and analyzed between May 1997 and January 1998. During this period about $93,203 \mathrm{~m}^{3}$ of macrophytes were removed from both reservoirs and disposed in nearby areas.

To evaluate the potential $\mathrm{Hg}$ transfer from aquatic plants to disposal areas, an estimate was made based on the biomass removed in dry weight, representing about $20 \%$ of total biomass removed, an estimate of plant organic matter density $\left(0.2-0.5{\mathrm{~g} . \mathrm{cm}^{-3}}^{-3}\right.$ and the mean $\mathrm{Hg}$ concentration in the leaves and roots of all aquatic macrophytes in the two reservoirs $\left(0.14 \mu \mathrm{g} . \mathrm{g}^{-1} \mathrm{dr}\right.$. wt. $)$. According to the above data, between 5 and $13 \mathrm{Kg}$ of $\mathrm{Hg}$ per year is transferred to disposal areas through aquatic macrophytes removed from the reservoirs. Compared with the total amount of $\mathrm{Hg}$ transported annually by the systems (Molisani et al., 2002), this may represent up to $10 \%$ of the total $\mathrm{Hg}$ transported. Once in soils, the $\mathrm{Hg}$ might be immobilized in soil organic matter, reach the pore water and return to the river systems or be reemitted into the environment through volatilization (Stein et al., 1996; Lindberg \& Meyers, 2001). Therefore, the potential importance of reservoir management strategies in the $\mathrm{Hg}$ dynamics of the RPS-Guandú system calls for more detailed studies on this subject.
Acknowledgements - This paper was supported by a PRONEXFAPERJ Program (Proc. E-26/171.175/2003) from the Fundação de Amparo à Pesquisa do Estado do Rio de Janeiro and the Ministry of Science and Technology, Brazil through its Instituto do Milênio Proc. ${ }^{\circ}$. 420.050/05. We thank the National Research Council of Brazil (CNPq) for conceding grants to the authors. Thanks are also due to the Light Electric Company staff for providing logistical assistance and information on the Paraíba do Sul River-Guandú Canal waterway.

\section{REFERENCES}

ALBERS, P. H. \& CAMARDESE, W. N., 1993, Effects of acidification on metal accumulation by aquatic plants and invertebrates. 1. Constructed wetlands. Environ. Toxicol. Chem., 12: 959-967.

AULA, I., BRAUNSCHWEILER H., LEINO, T., MALIN, I., PORVARI, P., HATANAKA, T., LODENIUS, M. \& JURAS, A., 1994, Levels of mercury in the Tucuruí reservoir and its surrounding area in Pará, Brazil, pp. 21-40. In: C. Watras \& J. Huckabee (eds.), Mercury Pollution, Integration and Synthesis, 740p., Lewis Publishers, Boca Raton.

AULA, I., BRAUNSCHWEILER, H. \& MALIN, I., 1995, The watershed flux of mercury examined with indicators in the Tucuruí reservoir in Pará, Brazil. Sci. Tot. Environ., 175: 97-107.

BINEY, C., AMUZU, A. T., CALAMARI, D., KABA, N., MBONE, I. L., NAEVE, H., OCHUMBA, P. B., OSIBANJO, O., RADEGONDE, V. \& SAAD, M. A., 1994, Review of heavy metals in the Africa aquatic environment. Ecotoxicol. Environ. Safety, 28: 134-159.

CAMPBELL, P. G. C., TESSIER, A., BISSON, M. \& BOUGIE, R., 1985, Accumulation of copper and zinc in the yellow water lily, Nuphar variegatum: Relationship to metal partitioning in the adjacent lake sediments. Can. J. Fish. Aquat. Sci., 42: 23-32.

COQUERY, M. \& WELBOURN, P. M., 1994, Mercury uptake from contaminated water and sediment by rooted and submerged aquatic Eriocaulaton septangulare. Arch. Environ. Contam. Toxicol., 26: 335-341.

COQUERY, M. \& WELBOURN, P. M., 1995, The relationship between metal concentration and organic matter in sediments 
and metal concentration in the aquatic macrophytes Eriocaulon septangulare. Wat. Res., 29: 2094-2102.

DUSHENKO, W. T., BRIGHT, D. A. \& REIMER, K. J., 1995, Arsenic bioaccumulation and toxicity in aquatic macrophytes exposed to gold-mine effluents - relationship with environmental partitioning, metal uptake and nutrients. Aquatic Botany, 50(2): 141-158.

GANTES, H. P. \& CARO, A. S., 2001, Environmental heterogeneity and spatial distribution of macrophytes in plain streams. Aquat. Bot., 70: 225-236.

GUENTZEL, J. L., POWELL, R. T., LANDING, W. M., GILL, G. A. \& POLLMAN, C. D., 1996, Mercury associated with colloidal material in an estuary and an open-ocean environment. Marine Chemistry, 55: 177-188.

GUIMARÃES, J. R. D., MEILI, M., HYLANDER, L. D., SILVA, E. C., ROULET, M., MAURO, J. B. N. \& LEMOS, R. A., 2000, Mercury net methylation in five tropical flood plain regions of Brazil: high in the root zone of floating macrophytes mats but low in surface sediments and flooded soils. Sci. Tot. Environ., 261: 99-107.

GUIMARÃES, J. R. D., MEILI, M., MALM, O. \& BRITO, E. M. S., 1998, Hg methylation in sediments and floating meadows of a tropical lake in the Pantanal floodplain, Brazil. Sci. Tot. Environ., 213: 165-175.

GONZÁLEZ, H., LODENIUS M. \& MARTINEZ, L., 1994, Removal of mercury from polluted waters by the water hyacinth (Eichhronia crassipes). Chem. Ecol., 9: 7-12.

GUPTA, M. \& CHANDRA, P., 1998, Bioaccumulation and toxicity of mercury in rooted-submerged macrophyte Vallisneria spiralis. Environ. Pollut., 10: 327-332.

HEEGAARD, E., BIRKS, H. H., GIBSON, C. E., SMITH, S. J. \& MURPHY, S. W., 2001, Species-environmental relationships of aquatic macrophytes in Northern Ireland. Aquat. Bot., 70: 175-223.

JACKSON, L. J., RASMUSSEN, J. B., PETERS, R. I. I. \& KALFF, J., 1991, Empirical relationship between the element composition of aquatic macrophytes and their underlying sediments. Biogeochemistry, 12: 71-86.

JACKSON, L. J., 1998, Paradigms of metal accumulation in rooted aquatic vascular plants. Sci. Tot. Environ., 219: 223-231.

LACERDA, L. D., PFEIFFER, W. C., MARINS, R. V., RODRIGUES, S., SOUZA, C. M. M. \& BASTOS, W. R., 1991, Mercury dispersal in water, sediments and aquatic biota of a gold mining tailing deposit drainage in Poconé, Brazil. Wat. Air Soil Pollut., 55: 283-294.
LACERDA, L. D. \& GONÇALVES, G. O., 2001, Mercury distribution and speciation in waters of the coastal lagoons of Rio de Janeiro, SE Brazil. Mar. Chem., 76: 47-58.

LINDBERG, S. E. \& MEYERS, T. P., 2001, Development of an automated micro-meteorological method for measuring the emission of mercury vapor from wetland vegetation. Wet. Ecol. Managt., 9: 333-347.

MARINS, R. V., LACERDA, L. D. \& VILLAS BOAS, R. C., 1999, Relative importance of non-point sources of mercury to an industrialized coastal system, Sepetiba Bay, SE Brazil, pp. 207-220. In: R., ebinghaus, R. R., Turner, L. D., Lacerda, O., Vasiliev, \& W., Salomons, (eds.), Mercury Contaminated Sites, 359p., Springer Verlag, Berlin.

MARTINELLI, L. A., FERREIRA, J. R., FORSBERG, B. R. \& VICTORIA, R. L., 1988, Mercury contamination on Amazon: a gold rush consequence. Ambio, 17: 252-254.

MAURY-BRACHET, R., RIBEYRE, F. \& BOUDOU, A., 1990, Actions and interactions of temperature and photoperiod on mercury accumulation by Elodea densa from sediment source. Ecotoxicol. Environ. Safety, 20: 141-155.

MOLISANI, M. M., MARINS, R. V., MACHADO, W. T., PARAQUETTI, H. H. M. \& LACERDA, L. D., 2002, Some implications of inter basin water transfers - Mercury Emission to Sepetiba Bay from Paraíba do Sul river, Brazil, pp. 113-117. In: L. D. Lacerda, H. Kremer, B. Kjerfve, W. Salomons \& J. C. Crossland, J. (eds.), South American Basins - SamBas: LOICZ Catchment Impacts on the Coastal Zone and Human Dimension, 212p., Publisher: IGBP-LOICZ, Texel.

OUTRIDGE, P. M. \& NOLLER, B. N., 1991, Accumulation of toxic trace elements by freshwater vascular plants. Rev. Environ. Cont. Toxicol., 121: 7-32.

SIMON, O. \& BOUDOU, A., 2001, Direct and trophic contamination of the herbivorous carp Ctenophatyngodon idella by inorganic mercury and methylmercury. Ecotoxicol. Environ. Safety, 50: 48-59.

STEIN, E. D., COHEN, Y. \& WINER, A. M., 1996, Environmental distribution and transformation of mercury compouds. Critical Rev Environ. Sci. Technol., 26: 1-43.

SUAREZ, Y. R., PETRERE, M. \& CASTELlA, A. C., 2001, Factors determined the structure of fish communities in Pantanal lagoons (MS, Brazil). Fish. Manag. Ecol., 8: 173-186.

VILLAR, C., STRIPEIKIS, J., TUDINO, M., D'HUICQUE, L., TROCCOLI, O. \& BONETTO, C., 1999, Trace metal concentrations in coastal marshes of the Lower Parana River and the Rio de la Plata Estuary. Hydrobiol., 397: 187-195. 